\title{
PERAN JAHE EMPRIT TERHADAP PENURUNAN INTENSITAS MUAL PADA PASIEN POST KEMOTERAPI
}

\author{
$\underline{\text { Umaroh }^{1} \text {, Agustin setiayingsih }}{ }^{2}$ \\ umazaini@gmail.com
}

\begin{abstract}
ABSTRAK
Mual merupakan masalah pada pasien post kemoterapi. Rasa mual berakibat menurunkan asupan nutrisi pada pasien post kemoterapi. Tujuan penelitian menganalisis intensitas mual pada pasien post kemoterapi (antiemetik konvensional) intervensi jahe emprit dan yang tidak.

Menganalisis perbedaan mual pada pasien post kemoterapi diberikan intervensi jahe dan tidak diberikan intervensi. Desain penelitian menggunakan post desain control grup.

Populasi pasien post kemoterapi penyakit gangguan reproduksi. Total sampel pada bulan Oktober - November 2015 di rumah Singgah Sehati Kota Semarang. Jumlah sampel 20 orang.

Hasil penelitian hari kemoterapi didapatkan nilai $\mathrm{P}=0.001$ alpha $5 \%$, min 0 max 4 mean 1,92, SD 1,605. Hari pertama post kemoterapi nilai $\mathrm{P}=0,0001$ alpah 5\%, Min 0, Max 3, Mean 1,62, SD 0,961. Hari ke 2 post kemoterapi nilai $\mathrm{P}=0,0001$ alpah 5\%,Min 0, Max 2, Mean 0,92, SD 0,641. Hari ke 3 post kemoterapi nilai $\mathrm{P}=0,0001$ alpah 5\%, Min 0, Max 2 Mean 0,630, SD 0,630. Ada perbedaan yang signifikan intensitas mual pada kasus dan kontrol.

Simpulan jahe dapat menurunkan mual pada pasien post kemoterapi. Perlu dilakukan sosialisasi minuman jahe pada pasien post kemoterapi.
\end{abstract}

Kata kunci; mual minum jahe

1,2Poltekkes Kemenkes Semarang

Mual (nausea) adalah sensasi atau perasaan yang sering merupakan gejala awal dari muntah. Gejala mual keringat dingin, pucat, hipersalivasi, hilang tonus gaster, kontraksi duodenum dan refluk isi intestinal ke dalam gaster sering menyertai mual meskipun tidak selalu disertai muntah 1. (Loadsman, 2005).

Mual dan muntah banyak terjadi pada pasien yang sedang mengalami kemoterapi. Hal ini disebabkan oleh karena obat yang digunakan mempunyai efek mual. Mual menga- kibatkan rasa tidak nyaman pada pasien dan menggangu asupan nutrisi sehingga banyak pasien komoterapi yang mengalami penuruanan kesehatan oleh karena kurangnya asupan nutrisi, daya tahan tubuh menurun hal ini berakibat komoterapi tahap berikutnya menjadi tertunda. Untuk mengurangi mual pada pasien kemoterapi digunakan obat obat antiemetikkonvensional. Tetapi masalah mual belum teratasi pada pasien komoterapi. Untuk mengatasi masalah diperlukan trobosan baru 
penggunaan obat - obat herbal tradisional dengan penggunaan tanaman jahe.

Jahe sendiri telah terdaftar pada dokumen 2.Generally Recognized as Safe (GRAS) di Food and Drug Administration (FDA) Amerika. Selama ini belum ada laporan terjadinya efek samping dan interaksi terhadap obat-obatan pada Germany's Commission E Monograph. Berdasarkan penelitian yang telah dilakukan sebelumnya, jahe dapat digunakan selama 3 bulan sampai dengan 2,5 tahun tanpa efek samping.

Pada penderita carsinoma stadium 4 terapi yang digunakan adalah dengan kemoterapi dan sinar cobalt, efek dari tindakan ini memacu munculnya sekresi salifa yang berlebihan dan sering disertai rasa mual 3.(Baziad, 2003). Jahe juga dapat digunakan untuk mencegah mual, karena jahe sendiri mampu memblok serotonin yaitu senyawa kimia yang dapat menyebabkan perut berkontraksi sehingga timbul rasa mual, membuat lambung menjadi nyaman 4 (Putra, 2013).

Efek antiradang pada jahe didukung dengan berbagai penelitian yang berhasil membuktikan efek antiradang jahe pada tikus, dilakukan 5.penelitian di Georgia pada tahun 2010 yang berhasil membuktikan bahwa pemberian ekstrak jahe sebanyak 2 gram per hari selama 10 hari mampu menurunkan nyeri otot sebesar $25 \%$. Studi lain yang dilakukan di Iran membuktikan bahwa jahe memiliki efek yang sama dengan ibuprofen dalam mengatasi gejala-gejala osteoarthritis, termasuk rasa nyeri 6.(Astuti, 2011). Berdasarkan data tersebut, peneliti tertarik untuk melakukan penelitian. Peran jahe emprit terhadap penurunan intensitas mual pada Pasien Post Kemoterapi.

Tujuan penelitian ini adalah Menganalisis mual pada pasien post kemoterapi (yang mendapatkan terapi antiemetik konvensional) dan diberikan intervensi dengan jahe emprit dan tidak diintervesi, serta menganalisis perbedaan mual pada pasien post kemoterapi yang diberikan intervensi jahe dan tidak diberikan intervensi.

Penelitian ini adalah penelitian eksperimen dengan desain posttest control group desain. Desain penelitian dengan menggunakan hubungan sebab akibat Satu kelompok subyek dan satu kelompok kontrol. Satu kelompok subyek diobservasi setelah diberikan perlakukan dan satu kelompok kontrol yang diobservasi tanpa diberikan perlakuan. Pengujian sebab akibat dilakukan dengan cara membanding-kan kedua subyek penelitian yaitu membandingkan subyek yang diberikan perlakukan dengan subyek yang tidak diberikan perlakukan.

Variable independen dalam penelitian ini adalah Intervensi Jahe emprit, sedangkan Variabel dependen dalam penelitian ini variabel dependen adalah Keluhan mual dan muntah. Sampel dalam penelitian ini adalah pasien post kemoterapi dengan penyakit gangguan reproduksi dan pasien sudah dilakukan kemoterapi lebih dari 3 kali. Metode pengumpulan data dilakukan dengan cara pengukuran mual menggunakan ceklist sensari rasa mual oleh pasein sendiri setelah sebelumnya minum jahe olahan.

Hasil dan pembahasan Analisa Univariat. Gambaran mual pada responden post kemoterapi yang diberikan intervensijahe emprit adalah sebagai berikut: 
Grafik 1.

Gambaran skor mual responden post kemoterapi yang diberikan intervensi jahe emprit pada hari ke 0 sampai hari ke- 3

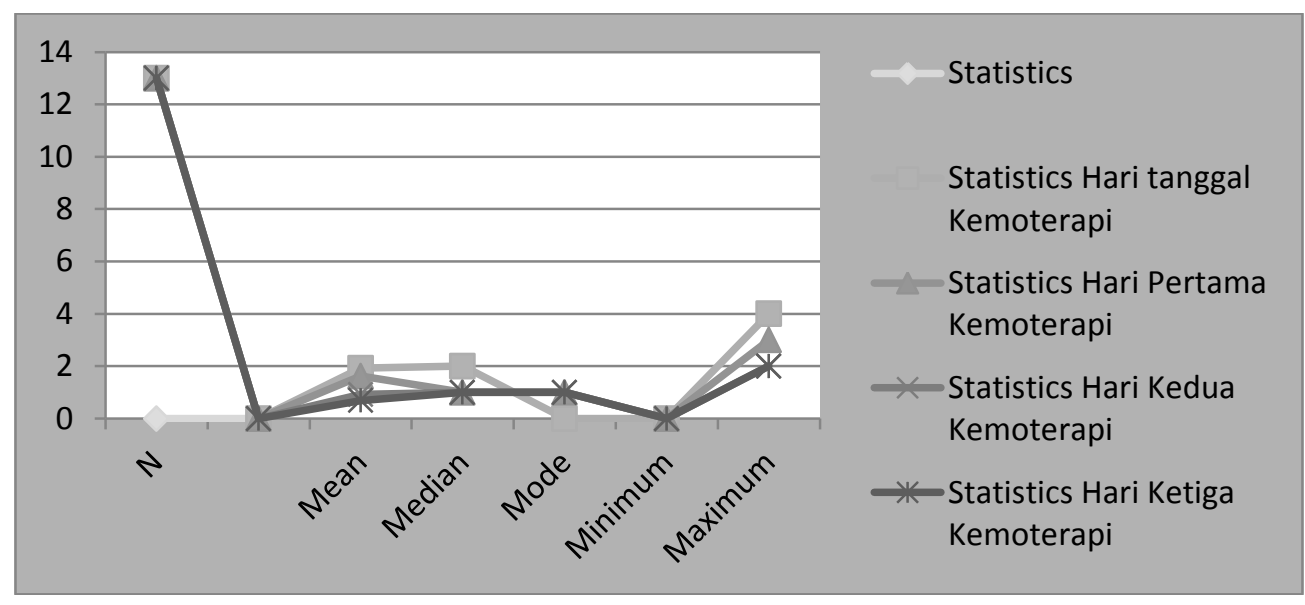

Pada grafik1. Gambaran mual pada responden post kemoterapi kelompok yang diberikan intervensi jahe emprit diperoleh bahwa bahwa rata-rata (mean) mengalami mual pada hari ke-0 (hari pada saat pemberian kemoterapi) sebesar 1,92 menurun sampai pada skor 0,69 . Nilai tengah mual pada responden yang diberikan intervensi mimunam jahe olahan pada hari ke 0 adalah 2 dan pada hari ke- 3 post kemoterapi adalah 1. Gambaran mual pada (kelompok intervensi) yang diberikan minuman jahe olahan skor minimun pada hari pertama dan sampai dengan hari ke- 3 adalah 0. Gambaran skor nilai maximum pada responden dengan intervensi mimuman jahe olahan pada hari ke - 0 adalah skor 4 dan nilai skor maximum pada hari ke3 responden post kemoterapi adalah 0 .

Distribusi frekuensi berdasarkan gambaran mual pada responden post kemoterapi yang tidak diberikan intervensi jahe emprit. Gambaran mual pada responden post kemoterapi yang tidak diberikan intervensi jahe emprit adalah sebagai berikut:

Garfik 2.

Gambaran skor mual pada hari ke 0 sampai hari ke-3 responden post kemoterapipada kelompok kontrol

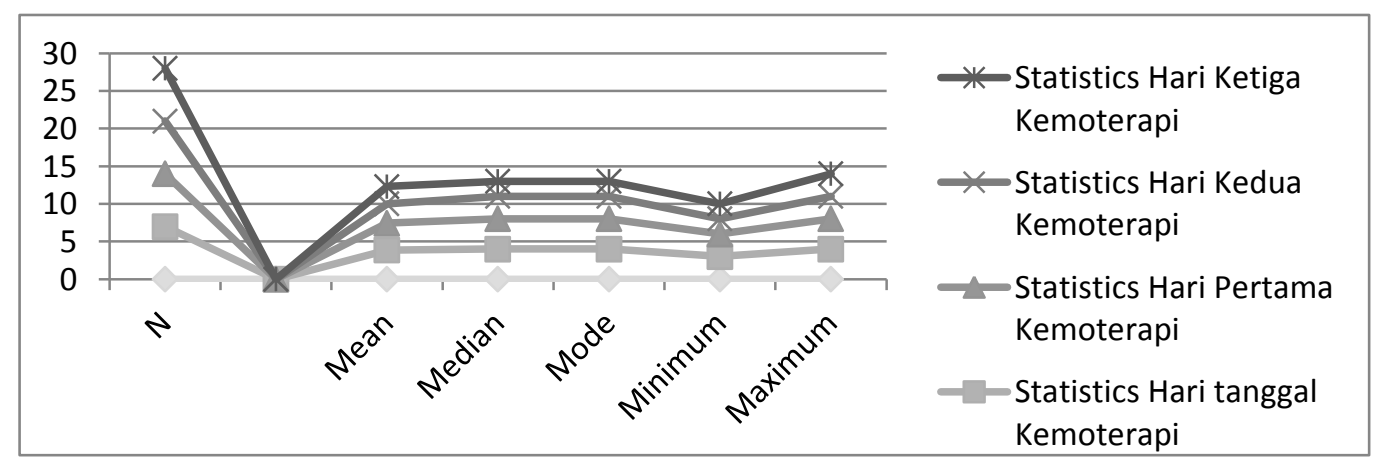


Pada grafik 2 gambaran rerata skor mual pada kelompok kontrol (tidak diberikan intervensi minuman jahe olahan) hari ke - 0 adalah 3.86 dan pada hari ke- 3 adalah 2,29. Nilai tengah mual pada responden yang tidak diberikan intervensi mimunam jahe olahan pada hari ke 0 adalah 4 dan pada hari ke- 3 post kemoterapi adalah 2. Gambaran mual pada (kelompok kontrol) yang tidak diberikan minuman jahe olahan skor minimun pada hari pertama adalah 3 dan pada hari ke- 3 adalah 2. Gambaran skor nilai maximum pada responden (kelompok kontrol) dengan yang tidak diberikan intervensi mimuman jahe olahan pada hari ke - 0 adalah skor 4 dan nilai skor maximum pada hari ke- 3 responden post kemoterapi adalah 3 .

Perbedaan mual pada responden post kemoterapi yang diberikan intervensi jahe emprit dan tidak diberikan intervensi.Perbedaan mual pada responden post kemoterapi yang diberikan intervensi jahe emprit dan tidak diberikan intervensi dapat dilihat pada tabel 3 berikut :

Tabel 3.

Perbedaanmualpadaresponden post kemoterapi yangdiberikan intervensi jahe dan tidak diberikanintervensijahe.

\begin{tabular}{|c|c|c|c|c|c|c|c|}
\hline No & $\begin{array}{c}\text { Hari } \\
\text { kemoterapi }\end{array}$ & Intervensi & Mean & $S D$ & $S E$ & $\begin{array}{c}P \\
\text { Value }\end{array}$ & $\mathrm{N}$ \\
\hline \multirow[t]{2}{*}{1.} & Hari ke-0 & Diberi jahe & 1.92 & 1.605 & 0.445 & \multirow{2}{*}{0.001} & 13 \\
\hline & & Tidak diberi & 3.86 & 0.378 & 0.143 & & 7 \\
\hline \multirow[t]{2}{*}{2.} & Hari ke-1 & Diberi jahe & 1.62 & 0.961 & 0.266 & \multirow{2}{*}{0.0001} & 13 \\
\hline & & Tidak diberi & 3.57 & 0.535 & 0.202 & & 7 \\
\hline \multirow[t]{2}{*}{3.} & Hari ke-2 & Diberi jahe & 0.92 & 0.641 & 0.178 & \multirow{2}{*}{0.0001} & 13 \\
\hline & & Tidak diberi & 2.57 & 0.535 & 0.202 & & 7 \\
\hline \multirow[t]{2}{*}{4.} & Hari ke-3 & Diberi jahe & 0.69 & 0.630 & 0.175 & \multirow{2}{*}{0.0001} & 13 \\
\hline & & Tidak diberi & 2.29 & 0.488 & 0.184 & & 7 \\
\hline
\end{tabular}

Berdasarkan tabel 4.1 Perbedaan mualpadaresponden post kemoterapi yang diberikan intervensi jahe emprit dan tidak diberikan intervensijahe emprit. Rata-rata mual pada responden post kemoterapi pada hari ke-0 yang diberikan intervensi jahe emprit lebih rendah sebesar 1.92 dengan standar deviasi 1.605 dibandingkan rata-rata responden post kemoterapi yang tidak diberikan intervensi jahe emprit sebesar 3.86 dengan standar deviasi 0.378. Hasil uji statistik didapatkan nilai $\mathrm{p}=0.001$, berarti pada alpha 5\% terlihat ada perbedaan yang signifikan mual pada responden post kemoterapi yang diberikan intervensi jahe emprit dengan yang tidak diberikan jahe emprit pada hari ke-0.

Rata-rata mual pada responden post kemoterapi pada hari ke-1 yang diberikan intervensi jahe emprit lebih rendah sebesar 1,62 dengan standar deviasi 0.961 dibandingkan rata-rata 
responden post kemoterapi yang tidak diberikan intervensi jahe emprit sebesar 3.57 dengan standar deviasi 0.535 . Hasil uji statistik didapatkan nilai $\mathrm{p}=0.0001$, berarti pada alpha $5 \%$ terlihat ada perbedaan yang signifikan mual pada responden post kemoterapi yang diberikan intervensi jahe emprit dengan yang tidak diberikan jahe emprit pada hari ke-1.

Rata-rata mual pada responden post kemoterapi pada hari ke-2 yang diberikan intervensi jahe emprit lebih rendah sebesar 0,92 dengan standar deviasi 0.641 dibandingkan rata-rata responden post kemoterapi yang tidak diberikan intervensi jahe emprit sebesar 2.57 dengan standar deviasi 0.535 . Hasil uji statistik didapatkan nilai $\mathrm{p}=0.0001$, berarti pada alpha $5 \%$ terlihat ada perbedaan yang signifikan mual pada responden post kemoterapi yang diberikan intervensi jahe emprit dengan yang tidak diberikan jahe emprit pada hari ke-2.

Rata-rata mual pada responden post kemoterapi pada hari ke-3 yang diberikan intervensi jahe emprit lebih rendah sebesar 0.69 dengan standar deviasi 0.630 dibandingkan rata-rata responden post kemoterapi yang tidak diberikan intervensi jahe emprit sebesar 2.29 dengan standar deviasi 0.488 . Hasil uji statistik didapatkan nilai $\mathrm{p}=0.0001$, berarti pada alpha $5 \%$ terlihat ada perbedaan yang signifikan mual pada responden post kemoterapi yang diberikan intervensi jahe emprit dengan yang tidak diberikan jahe emprit pada hari ke-3.

Hasil penelitian ini, menunjukkan bahwa responden yang diberikan intervensi jahe emprit rata-rata mengalami mual pada hari ke-0 (saat mendapatkan kemoterapi) yaitu sebesar 1.92 demikian pula dengan responden yang tidak diberikan intervensi jahe emprit rata-rata paling banyak mengalami keluhan mual pada hari ke-0 (saat mendapatkan kemoterapi) yaitu sebesar 3.86. Hasil penelitian sesuai dengan penelitian 7. Naga (2011) yang mengatakan bahwa pasien mengalami emisis 1-2 jam setelah pemberian kemoterapi atau bisa juga akan timbul kembali setelah 48-72. Emisis yang timbul dalam waktu 24 jam setelah kemoterapi disebut emisis akut. Ratarata mual responden yang diberikan intervensi jahe pada hari ke-0 (hari saat pemberian kemoterapi, tepatnya diminum sebelum dilakukan kemoterapi) lebih rendah dibandingkan yang tidak diberikan intervensi. Hal ini, menunjukkan bahwa jahe mempunyai pengaruh menekan mual yang meru-pakan efek samping kemoterapi.

Hasil penelitian juga membuktikan bahwa responden yang diberikan intervensi jahe emprit selama 4 hari (hari ke-0 sampai hari ke-3) akan mengalami penurunan rasa mual berdasarkan keluhan yang dirasakan pada hari ke-0 yaitu responden mengalami mual sekali tidak bisa makan dan minum pada hari ke-0 (setelah pemberian kemoterapi), namun pada hari ke-3 responden yang diberikan intervensi jahe emprit meskipun masih merasakan mual, tetapi bisa makan 1-2 sendok dan minum 2 gelas. Selain itu, pemberian jahe emprit pada responden yang mendapatkan kemoterapi juga ada yang memberikan pengaruhterhadap respondensama sekali tidak mengalami rasa mual setelah pemberian kemoterapi pada hari ke-0, ke-1,ke-2 maupun hari ke-3. Rata-rata mual pada responden post kemoterapi yang diberikan intervensi jahe emprit pada hari ke-0, ke-1,ke-2 dan ke-3 ( $x=1.92-0.69)$ 
lebih rendah dibandingkan dengan ratarata mual responden post kemoterapi yang tidak diberikan intervensi jahe emprit sebesar ( $x=3.86-2.29$ ). Hasil uji statistik didapatkan nilai $\mathrm{p}=0.001$ (pada hari ke-0) dan $\mathrm{p}=0.0001$ (pada hari ke-1,2 dan 3), yang artinya pada alpha 5\% terlihat ada perbedaan yang signifikan mual pada responden post kemoterapi yang diberikan intervensi jahe emprit dengan yang tidak diberikan jahe pada hari ke-0,1,2 dan 3 .

Berdasarkan bukti-bukti hasil penelitian tersebut, menunjukkan bahwa suplementasi jahe efektif terhadap gejala mual akibat kemoterapi dan pengurangan rasa mual dapat memperbaiki kualitas hidup sebagian besar pasien selama kemoterapi.

\section{SIMPULAN.}

Gambaran mual pada pasien post kemoterapi yang diberikan intervensi jahe emprit rata-rata mengalami mual pada hari ke-0 yaitu sebesar 1.92. pada hari ke- 1 rata - rata mual sebesar 1,62. Hari ke- 2 post kemoterapi rata - rata mual sebesar 0,92 sedangkan hari ke-3 post kemoterapi rata - rata mual sebesar 0,69.

Gambaranmualpadaresponden post kemoterapi yang tidak diberikan intervensi jahe emprit pada hari ke-0 sebesar 3.86 hari ke-1 post kemoterapi 3,57 . Rata - rata mual pada hari ke-2 post kemoterapi yaitu 2,57 dan hari ke3 post kemoterapi rata - rata mual responden sebesar 2,29.

Perbedaan mual pada responden post kemoterapi yang diberikan intervensi jahe emprit dan tidak diberikan intervens. Rata-rata mual pada responden post kemoterapi yang diberikan intervensi jahe emprit pada hari ke-0, ke-1,ke-2 dan ke-3 ( $\mathrm{x}=1.92$ 0.69 ) lebih rendah dibandingkan dengan rata-rata mual responden post kemoterapi yang tidak diberikan intervensi jahe emprit sebesar ( $\mathrm{x}=$ 3.86-2.29 ). Hasil uji statistik didapatkan nilai $\mathrm{p}=0.001$ (pada hari ke0) dan $\mathrm{p}=0.0001$ (pada hari ke-1,2 dan 3 ), yang artinya pada alpha 5\% terlihat ada perbedaan yang signifikan mual pada responden post kemoterapi yang diberikan intervensi jahe emprit dengan yang tidak diberikan jahe emprit pada hari ke-0,1,2 dan 3.

Berdasarkan hasil analisa data yang mrenunjukan adanya peran jahe terhadap penurunan intensitas mual pada paseien post kemoterapi maka saran yang diberikan adalah sebagai berikut. Bagi Masyarakat (khususnya penderita kanker) yang menjalani kemoterapi hendaknya memanfaatkan pengobatan herbal (jahe emprit) untuk mengatasi mual setelah pemberian kemoterapi.

Tenaga kesehatan hendaknya membantu mensosialisasikan dan memfasilitasi kerjasama lintas sektor untuk dapat mengembangkan minuman jahe empritolahan untuk mengurangi mual setelah kemoterapi pada masyarakat.

Bagi peneliti selanjutnya hendaknya dapat meneliti lebih lanjut manfaat jahe emprit untuk mengurangi keluhan dari penyakit dan terapi yang berbeda. 


\section{DAFTAR PUSTAKA}

Alimul, A.A. 2003. Riset Keperawatan dan Tehnik Penulisan Ilmiah. Jakarta: Salemba Medika.

Arikunto, S. 2006. Prosedur Penelitian Suatu Pendekatan Praktik. Jakarta : Rineka Cipta

Astuti, Ambar Dwi. 2011. Efektivitas Pemberian Ekstrak Jahe Merah (Zingiber Officinale Roscoe Varr Rubrum) Dalam Mengurangi Nyeri Otot Pada Atlet Sepak Takraw. Universitas Diponegoro. http:// eprints.undip.ac.id/32557/1/381_Am bar_Dwi_Widhi_Astuti_G2C00700 6.pdf. (diakses tanggal 22 April 2013)

Barbara, Z \& Glenora. 1997. Fundamentals of Nursing Second Edition. California-USA: Addison Wesley Publising Company

Baziad, Ali. 2003. Endokrinologi Ginekologi. Jakarata : fakultas kedokteran Universitas Indonesia

2008. Endokrinologi Ginekologi. Jakarata: media Aes-culapius Fakultas Kedokteran Universitas Indonesia

Berman, Audrey, et all. 2009. Buku Ajar Praktik Keperawatan Klinis Kozier \& Erb. Jakarta : EGC

Brunner \& Suddart. 2002. Buku Ajar Medikal Bedah Edisi 8. Jakarta: EGC

Budiarto, E. Biostatistika untuk Kedokteran dan Kesehatan Masyarakat. Jakarta: EGC

Dahlan, M. Sopiyudin. 2009. Besar Sampel dan Cara Pengambilan
Sampel dalam Penelitian Kedokteran dan Kesehatan. Jakarta : Salemba Medika

2010. Membuat

Proposal Penelitian Bidan Kedokteran dan Kesehatan. Jakarta : Salemba Medika

Dewi, Ocha Septia. 2013. Herbal Taklukan Ragam Penyakit. Jogjakarta : Flash Books

Fakri ,faizal M.. 2012. 1001 Khasiat Dan Manfaat Jamu Gendong untuk Segala Macam Penyakit. Yogyakarta : Diandra Pustaka Indonesia

Fathonah, Difa. 2011. Kandungan Gingerol dan Shogaol, Intensitas Kepedasan dan Penerimaan Panelis terhadap Oleoresin Jahe Gajah (Zingeber officinale var. Roscoe), Jahe Emprit (Zingeber officinale var. Amarum), dan Jahe Merah (Zingeber officinale var. Rubrum). Fakultas teknologi pertanian Institut Pertanian Bogor.

http://repository.ipb.ac.id/handle/12345 $\underline{6789 / 51192}$ (Diakses tanggal 18 Mei 2013)

Geri. Morgan. 2009. Obstetri \& gineko logi: panduan praktik. Jakarta : EGC

Herlina R, Murhananto JE, Listyarini T, dan Pribadi ST. 2002. Khasiat dan Manfaat Jahe Merah: Si Rimpang Ajaib. Media Pustaka. Jakarta

Hidayat, A. 2007. Metodologi Penelitian Kebidanan Teknik Analisa Data. Jakarta: Salemba Medika

Isselbacher, et al. 1999. Harrison: Prinsip-prinsip Ilmu Penyakit Dalam Edisi 13 Volum 1. Jakarta : EGC 
Naga, Dali S. Naga, 2011. Ukuran Efek

Koswara S. 1995. Jahe dan Hasil dalam Laporan Hasil Penelitian. Dalam http://dali.staff. gunadarma. ac.id/Publications/files/399/4861aARCHE.doc.

Meltzer, David E. (2002). "The Relationship Beetwen Mathemathic Preparation and Conceptual Learning Gain in Physics: A Possible "Hidden Variable" in Diagnostic Pretest Scores." American Journal of Physics 70 (12). Hlm 1259-1267.

Notoatmodjo, S. 2003. Pendidikan dan Perilaku Kesehatan. Jakarta : Rineka Cipta 2010. Metodologi Penelitian Kesehatan. Jakarta : Rineke Cipta

Nursalam. 2007. Konsep dan Penerapan Metodologi Penelitian Ilmu Keperawatan. Jakarta: Salemba Medika

Potter \& Perry. 2005. Fundamental Keperawatan Volume 2. Jakarta: EGC

Prawirohardjo, Sarwono. 2008. Ilmu Kebidanan.Jakarta: PT Bina Pustaka

Putra, Winkanda Satria. 2013. Sehat dengan Herbal Tanpa Dokter. Yogyakarta : Citra Media

Rismunandar, 1988. Rempah-rempah Komoditi Ekspor Indonesia. Bandung : CV Sinar Baru

Santoso, Hieronymus Budi. 1988. Kanisius. 